\title{
Marine diversity shift linked to interactions among grazers, nutrients and propagule banks
}

\author{
Boris Worm ${ }^{1, *}$, Heike K. Lotze ${ }^{1}$, Christoffer Boström ${ }^{2}$, Roland Engkvist ${ }^{3}$, Vytautas Labanauskas ${ }^{4}$, \\ Ulrich Sommer ${ }^{1}$ \\ 'Institut für Meereskunde, Düsternbrooker Weg 20, D-24105 Kiel, Germany \\ ${ }^{2}$ Åbo Akademi University, Husö Biological Station, FIN-22220 Emkarby, Åland Islands, Finland \\ ${ }^{3}$ Institute of Natural Sciences, University of Kalmar, PO Box 905, S-39129 Kalmar, Sweden \\ ${ }^{4}$ Center for System Analysis, Klaipeda University, Manto 84, 5808 Klaipeda, Lithuania
}

\begin{abstract}
Diverse coastal seaweed communities dominated by perennial fucoids become replaced by species-poor turfs of annual algae throughout the Baltic Sea. A large-scale field survey and factorial field experiments indicated that grazers maintain the fucoid community through selective consumption of annual algae. Interactive effects between grazers and dormant propagules of annual algae, stored in a 'marine seed bank', determine the response of this system to anthropogenic nutrient loading. Nutrients override grazer control and accelerate the loss of algal diversity in the presence but not in the absence of a propagule bank. This implies a novel role of propagule banks for community regulation and ecosystem response to marine eutrophication.
\end{abstract}

KEY WORDS: Coastal ecosystems - Eutrophication - Baltic Sea Macroalgae - Diversity - Community structure - Dormancy $\cdot$ Herbivory Fucus vesiculosus

Most ecosystems today are dominated by human influences (Vitousek et al. 1997). The individual responses of ecosystems however are highly variable and may depend on food-web structure (Leibold \& Wilbur 1992), species diversity (Schulze \& Mooney 1993) and probably other factors that mediate dampening or reinforcing feedbacks within the system. We present observational and field experimental evidence that the response of the Baltic coastal ecosystem to human nutrient overloading depends on food-web structure (grazer abundance and type) and on the presence of recently described algal propagule banks (Santelices et al. 1995, Lotze et al. 1999) and that these factors do not operate independently.

\footnotetext{
•E-mail: bworm@ifm.uni-kiel.de
}

The global overloading of ecosystems with the limiting plant nutrients nitrogen and phosphorus is one of the major anthropogenic alterations of biogeochemical cycles (Vitousek et al. 1997, Carpenter et al. 1998). In the Baltic Sea, a human-induced doubling of dissolved nitrogen and phosphorus pools in surface and deep waters has been documented from 1958 to 1990 (Nehring 1987, 1991). Perennial seaweeds (mostly the brown rockweed Fucus vesiculosus [hereafter Fucus]), which have structurally and functionally dominated the rocky littoral ecosystem, declined rapidly throughout this period (reviewed by Kautsky et al. 1992, Schramm 1996). Their loss leads to declining macrobenthic diversity and fishery yield through loss of spawning and juvenile habitat (Kautsky et al. 1992), and changes nutrient cycling and carbon storage (B. Worm unpubl.) and possibly other ecosystem services which are usually provided by perennial macrophyte communities. Globally, these services were recently valued as US $\$ 3.8$ trillion $\left(10^{12}\right)$ per year, equaling the total value of services provided by tropical rain forests (Costanza et al. 1997).

Based on available observational evidence a number of hypotheses (including among others: overgrazing, shading by phytoplankton and epiphytes, recruitment inhibition) have been forwarded to explain these changes (reviewed by Schramm 1996). Surprisingly, none of these has been tested experimentally. Chlorophyll data from a Swedish location indicate that increasing nutrient levels have increased phytoplankton biomass, which may explain documented changes in the depth limit of the Fucus zone (Kautsky et al. 1986), but not widespread dramatic declines (Vogt \& Schramm 1991) or extirpation (Olenin \& Klovaite 1998) of fucoid communities throughout its depth range (usually 0 to 5 [max. 12] $\mathrm{m}$ ). 
We quantified patterns of algal and grazer abundances at 25 shallow sites throughout the Baltic. Then we used a factorial field experiment to provide a mechanistic explanation for these patterns. We tested the hypotheses that grazers, nutrients and algal propagule supply (newly dispersed propagules versus dormant propagules) are key variables that determine abundance and diversity of macroalgal species in the nearshore ecosystem.

Materials and methods. We conducted a field survey across 25 sites in 4 countries in order to detect patterns in the abundance of grazers and annual and perennial algae in the Baltic. This was done during the reproductive period of Fucus (May in western Baltic to July in northern Baltic) because only at this time does Fucus generate propagules which can occupy new space and because these early life-history stages may be the most vulnerable to competition and herbivory (Lubchenco 1986, Worm \& Chapman 1996, 1998). We surveyed 15 sites in the Kiel Bight, Germany $\left(54^{\circ} 12^{\prime} \mathrm{N}, 11^{\circ} 03^{\prime} \mathrm{E}\right.$ to $\left.54^{\circ} 55^{\prime} \mathrm{N}, 9^{\circ} 48^{\prime} \mathrm{E}\right), 4$ sites at the Swedish east coast $\left(56^{\circ} 14^{\prime} \mathrm{N}, 16^{\circ} 02^{\prime} \mathrm{E}\right.$ to $\left.57^{\circ} 21^{\prime} \mathrm{N}, 16^{\circ} 37^{\prime} \mathrm{E}\right), 4$ sites in the Aland archipelago, Finland $\left(60^{\circ} 20^{\prime} \mathrm{N}, 19^{\circ} 36^{\prime} \mathrm{E}\right.$ to $60^{\circ} 23^{\prime} \mathrm{N}, 19^{\circ} 43^{\prime} \mathrm{E}$ ), and 2 sites along the Lithuanian open shore $\left(55^{\circ} 50^{\prime} \mathrm{N}, 21^{\circ} 03^{\prime} \mathrm{E}\right.$ to $\left.55^{\circ} 55^{\prime} \mathrm{N}, 21^{\circ} 02^{\prime} \mathrm{E}\right)$. At each site, 10 replicate frames $(25 \times 25 \mathrm{~cm})$ were placed randomly along 100 to $150 \mathrm{~m}$ transects at 0.8 to $1.2 \mathrm{~m}$ depth. Percent cover of attached algae and sessile invertebrates on rocky surface (no epiphytes or drifting plants) was determined using a Plexiglas frame with 50 random points. Grazers were removed by shaking the algae within a framed sampling net and counted. Data were pooled for each site and analyzed by linear and multiple regression models (Sokal \& Rohlf 1995), with Fucus cover as the dependent and (1) annual algal cover, (2) crustacean grazer density, and (3) gastropod grazers grazer density as the independent variables.

In a field experiment we analyzed the role of grazers (gastropods Littorina spp., and crustaceans Idotea spp. and Gammarus spp.) in combination with manipulations of algal propagule supply and nutrient loading. We ran the experiment in a sheltered embayment at Maasholm, Germany, Baltic Sea $\left(54^{\circ} 41^{\prime} \mathrm{N}, 10^{\circ} 00^{\prime} \mathrm{E}\right)$. A detailed description of the site is given by Lotze (1998). We manipulated grazers, propagule banks and nutrient loading in a fully crossed $2 \times 2 \times 2$ design ( $n=4$ per treatment combination). Grazer exclusion and manipulations of the propagule bank started immediately after the breakup of sea ice in February 1997. As experimental substrata we collected flat granite rocks $(20 \mathrm{~cm}$ diameter) without macroscopic plant cover from the Fucus zone. Half of the rocks were heat-sterilized to remove the propagule bank and randomly assigned to 4 blocks of 12 plots each in a natural stand of Fucus at
$0.8 \mathrm{~m}$ water depth. Grazers were excluded with cages $(25 \times 25 \times 25 \mathrm{~cm})$ covered with clear $1 \mathrm{~mm}$ polyethylene mesh. Half of the cages had one side cut open to allow access for grazers, and a set of uncaged control plots was also established. All cages were cleaned with a brush weekly to prevent fouling. Nutrient diffusers (mesh rolls filled with $160 \mathrm{~g}$ coated slow-release fertilizer, Plantacote Depot, Urania Agrochem, Hamburg) were added from 20 June to 30 September to increase the availability of nutrients during summer nutrient depletion. Three-weekly measurements on all plots revealed that, on average, $\mathrm{NH}_{4}{ }^{+}$concentrations on the enriched plots increased by $180 \%, \mathrm{NO}_{3}{ }^{-}$by $120 \%$ and $\mathrm{PO}_{4}{ }^{3-}$ by $35 \%$. Concentrations for these nutrients ranged between 0.1 and $4.2 \mu \mathrm{mol} \mathrm{l}^{-1}$ in control and 0.7 and $7.3 \mu \mathrm{mol} \mathrm{I}^{-1}$ in enriched plots. On 20 June and 30 August algal cover on a central $10 \times 10 \mathrm{~cm}$ area on each rock was determined for each species separately with a Plexiglas frame with 50 random points. We calculated macroalgal species diversity using the Shannon-Weaver Index $H^{\prime}$ (number of species per $100 \mathrm{~cm}^{2}$ area, weighed by their relative abundance expressed as percent cover). Species cover data were angular transformed (Sokal \& Rohlf 1995) and analyzed by MANOVA, using the Pillai trace statistic (Johnson \& Field 1993). This approach evaluates experimental effects on all species simultaneously, taking interdependencies into account. Diversity data and total plant cover data were analyzed by factorial ANOVA. Logarithmic transformation was applied to total cover data to achieve homogeneity of variances.

Results. When we surveyed 25 sites from 4 countries we found that Fucus was the only perennial species in the shallow zone, except for 1 site in Sweden (Figeholm, $57^{\circ} 21^{\prime} \mathrm{N}, 16^{\circ} 37^{\prime} \mathrm{E}$ ), where Furcellaria lumbricalis occurred at low densities. Coverage of Fucus was negatively correlated with cover of filamentous or foliose annual algae such as Enteromorpha intestinalis, Ceramium rubrum, Cladophora glomerata or Pilayella littoralis throughout the Baltic Sea (Fig. 1A). Fucus cover was strongly positively correlated with the density of gastropod grazers (Fig, 1B) and cover of annual algae was negatively correlated with gastropod densities $\left(y=66.37-0.034 x, p=0.03, r^{2}=0.18\right)$. In a multiple regression model predicting Fucus cover at a given site, the effects of annual algae cover $(p<0.0001)$ and gastropod grazers $(p=0.0009)$ were significant, but the effect of crustacean grazers was insignificant ( $\mathrm{p}=$ 0.52). This model explained $>76 \%$ of variation in Fucus cover (overall $\mathrm{r}^{2}=0.765, \mathrm{n}=25, \mathrm{p}<0.0001$ ). Sessile invertebrates were relatively rare and did not explain a significant part of the variance in Fucus cover $(p>0.2)$.

In our field experiment algal community structure (species composition, abundance, diversity) was strongly 


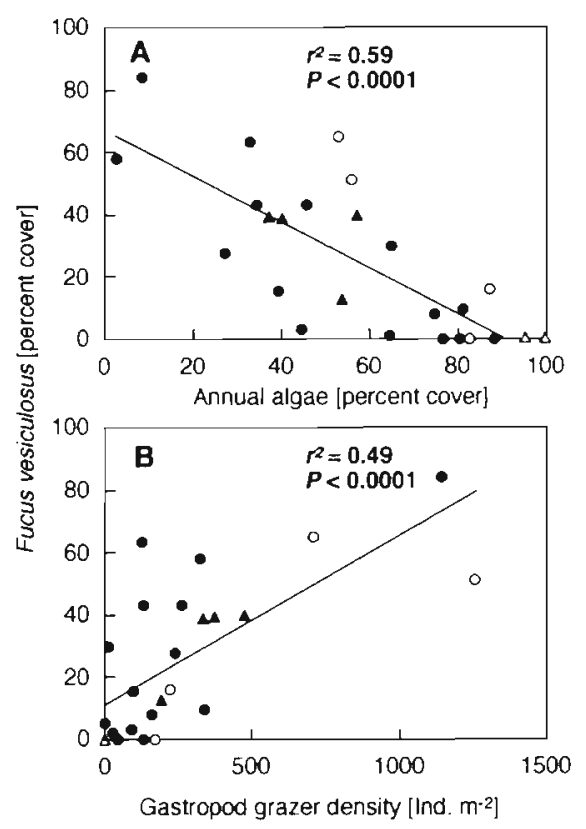

Fig. 1. Large-scale relationships among perennial fucoids, annual algae and gastropod grazers in the Baltic. Fucus vesiculosus cover is predicted from the abundance of (A) annual space competitors $(y=68.057-0.738 x)$ and (B) gastropod grazers (western Baltic: Littorina spp.; eastern and northern Baltic, Teodoxus fluviatilis, $y=11.091+0.054 x)$. The survey covered 25 sites in Germany ( $\bullet$ ), Sweden (0), Finland ( $\bullet$ ) and Lithuania $(\Delta)$

influenced by the presence of grazers and algal propagule banks (Fig. 2, Table 1). Grazers reduced the total cover of annual algae and prevented space monopolization by the fast-growing green annual Enteromorpha spp. (Fig. 2A), thereby maintaining species diversity (Fig. 2B). The presence of propagule banks increased total cover of annual algae and dominance of Enteromorpha spp., which caused algal diversity to decline. Grazers and propagule banks had opposite and independent effects on species composition and diversity (Table 1) and total plant cover (ANOVA, Grazer $F_{1,28}=13.87, \mathrm{p}=0.0009$, Propagule Bank $F_{1,28}=6.21, \mathrm{p}=0.019$, Grazer $\times$ Propagule Bank, $F_{1.28}=2.09, \mathrm{p}=0.16$ ). Fucus cover was low initially (Fig. 2A), but increased in subsequent months (Fig. 3A) following spring recruitment.

Species composition and diversity responded differently to nutrient enrichment, depending on the effects of grazers and propagule banks, as indicated by 3 way interactions in the analysis (Table 1). Enrichment tended to decrease diversity $(\mathrm{p}=0.031)$, mainly by increasing the relative dominance of Enteromorpha spp. at the expense of Fucus. (Fig. 3A). However, this shift only occurred in treatments with both the propagule bank and grazers either present or absent (Fig. 3B). Nutrients had no effects on diversity if only the prop-

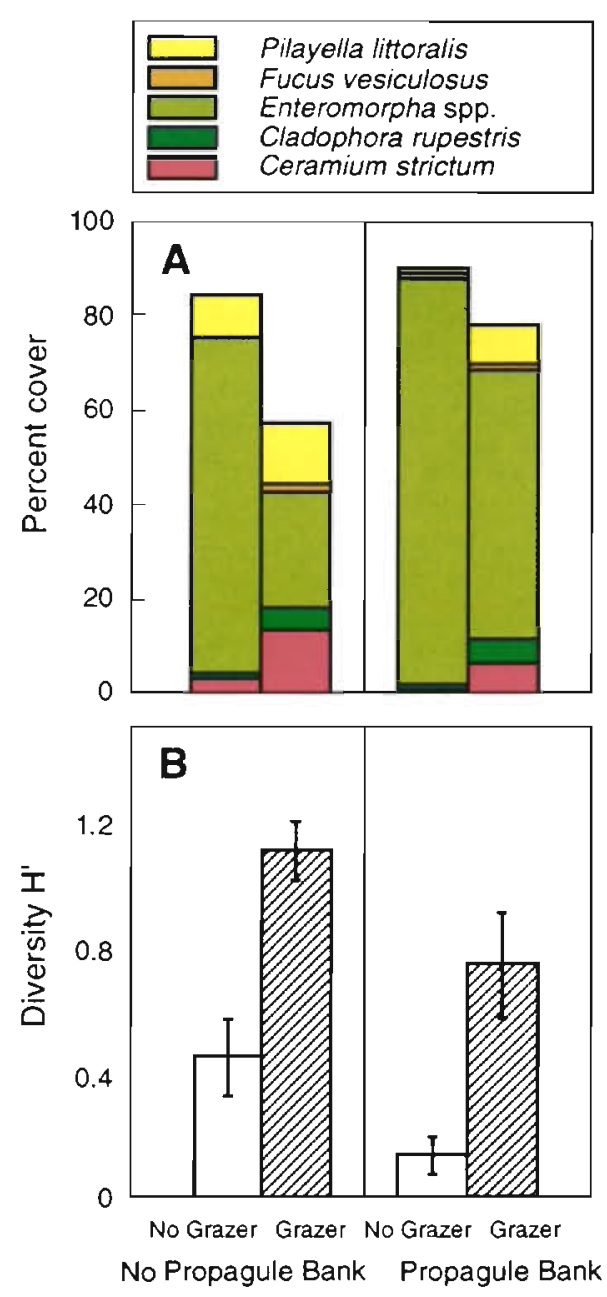

Fig. 2. Community structure. (A) Algal species composition and abundance and $(B)$ diversity $( \pm 1 \mathrm{SE}$ ) as measured by the Shannon-Weaver index are shown in relation to the presence of grazers and algal propagule banks (June, before nutrient enrichment). For ANOVA results see Table 1. Enteromorpha spp. is $>80 \% E$. intestinalis, mixed with $E$. prolifera and E. clathrata

agule bank (strong Enteromorpha spp. dominance) or grazers were present (strong Fucus dominance). Presence of the propagule bank increased total plant cover independently of nutrient addition (ANOVA, Nutrients $\times$ Propagule Bank, $F_{1,24}=0.66, p=0.42$ ). However, grazers decreased total plant cover only when nutrients were not enriched (ANOVA, Nutrients $\times$ Grazer, $F_{1,24}=5.45, \mathrm{p}=0.026$ ).

Comparison of control plots and open cages revealed no cage effects on algal diversity (ANOVA, $F_{1.24}=0.93$, $\mathrm{p}=0.34$ ); however, there were cage effects on species composition (MANOVA, $F_{4,21}=10.2, p<0.0001$ ) because of increased Enteromorpha spp. cover in the cages. This is likely caused by the reduced grazer pressure in the open cages, due to the weekly brushing procedure, 
Table 1. Analysis of changes in species composition (MANOVA, Pillai Trace statistic) and species diversity (3-way factorial ANOVA) before and after experimental nutrient enrichment. G: Grazer, PB: Propagule Bank, N: Nutrients. Bold $p$-values are $p<0.1$

\begin{tabular}{|c|c|c|c|c|c|}
\hline Dependent variable & Source & $\mathrm{df}$ & MS & $F$ & $\mathrm{p}$ \\
\hline $\begin{array}{l}\text { Species composition } \\
\text { before enrichment }\end{array}$ & $\begin{array}{l}\text { Grazer } \\
\text { Propagule Bank } \\
\text { G×PB }\end{array}$ & $\begin{array}{l}4,23 \\
4,23 \\
4,23\end{array}$ & $\begin{array}{l}0.51 \\
0.36 \\
0.13\end{array}$ & $\begin{array}{l}5.64 \\
3.13 \\
0.84\end{array}$ & $\begin{array}{l}0.0028 \\
0.0352 \\
0.5130\end{array}$ \\
\hline $\begin{array}{l}\text { Species composition } \\
\text { after enrichment }\end{array}$ & $\begin{array}{l}\text { Grazer } \\
\text { Propagule Bank } \\
\text { Nutrients } \\
\mathrm{G} \times \mathrm{PB} \\
\mathrm{G} \times \mathrm{N} \\
\mathrm{PB} \times \mathrm{N} \\
\mathrm{G} \times \mathrm{PB} \times \mathrm{N}\end{array}$ & $\begin{array}{l}3,22 \\
3,22 \\
3,22 \\
3,22 \\
3,22 \\
3,22 \\
3,22\end{array}$ & $\begin{array}{l}0.42 \\
0.66 \\
0.09 \\
0.09 \\
0.12 \\
0.04 \\
0.27\end{array}$ & $\begin{array}{l}5.27 \\
14.34 \\
0.76 \\
0.74 \\
0.95 \\
0.31 \\
2.72\end{array}$ & $\begin{array}{l}\mathbf{0 . 0 0 6 8} \\
\mathbf{0 . 0 0 0 1} \\
0.5277 \\
0.5417 \\
0.4326 \\
0.8166 \\
\mathbf{0 . 0 6 9 4}\end{array}$ \\
\hline $\begin{array}{l}\text { Diversity }\left(H^{\prime}\right) \\
\text { before enrichment }\end{array}$ & $\begin{array}{l}\text { Grazer } \\
\text { Propagule Bank } \\
\text { G×PB } \\
\text { Residual }\end{array}$ & $\begin{array}{c}1 \\
1 \\
1 \\
28\end{array}$ & $\begin{array}{l}3.25 \\
0.93 \\
0.01 \\
0.11\end{array}$ & $\begin{array}{c}29.55 \\
8.41 \\
0.04\end{array}$ & $\begin{array}{l}\mathbf{0 . 0 0 0 1} \\
\mathbf{0 . 0 0 7 2} \\
0.8403\end{array}$ \\
\hline $\begin{array}{l}\text { Diversity }\left(H^{\prime}\right) \\
\text { after enrichment }\end{array}$ & $\begin{array}{l}\text { Grazer } \\
\text { Propagule Bank } \\
\text { Nutrients } \\
\mathrm{G} \times \mathrm{PB} \\
\mathrm{G} \times \mathrm{N} \\
\mathrm{PB} \times \mathrm{N} \\
\mathrm{G} \times \mathrm{PB} \times \mathrm{N} \\
\text { Residual }\end{array}$ & $\begin{array}{c}1 \\
1 \\
1 \\
1 \\
1 \\
1 \\
1 \\
24\end{array}$ & $\begin{array}{l}0.18 \\
0.07 \\
0.34 \\
0.24 \\
0.01 \\
0.00 \\
0.29 \\
0.07\end{array}$ & $\begin{array}{l}2.83 \\
1.13 \\
5.27 \\
3.76 \\
0.18 \\
0.00 \\
4.47\end{array}$ & $\begin{array}{l}0.1056 \\
0.2983 \\
\mathbf{0 . 0 3 0 7} \\
\mathbf{0 . 0 6 4 4} \\
0.6791 \\
0.9648 \\
\mathbf{0 . 0 4 5 0}\end{array}$ \\
\hline
\end{tabular}

which reduced the average density of the slow-moving snail Littorina saxatilis (Lotze 1998), but not of other grazer species. Thus, estimates of grazer impacts in the cage experiment must be considered a conservative estimate of natural grazer impact at Maasholm.

Discussion. These results suggest that grazers play a key role in the Baltic nearshore ecosystem in maintaining a species-rich community, which is typically dominated by long-lived fucoids. Our large-scale survey complements earlier local reports (reviewed by Schramm 1996) that indicated a shift from the Fucus community to lowdiversity turfs of annual algae. Across the Baltic, we identified annual algal cover and gastropod grazer densities as important variables that may influence these changes (Fig. 1). Field experiments corroborated this concept and showed how propagule supply and anthropogenic nutrient overloading affect grazer-algae interactions. Algal propagule banks at our site contain high densities of Enteromorpha spp. spores or
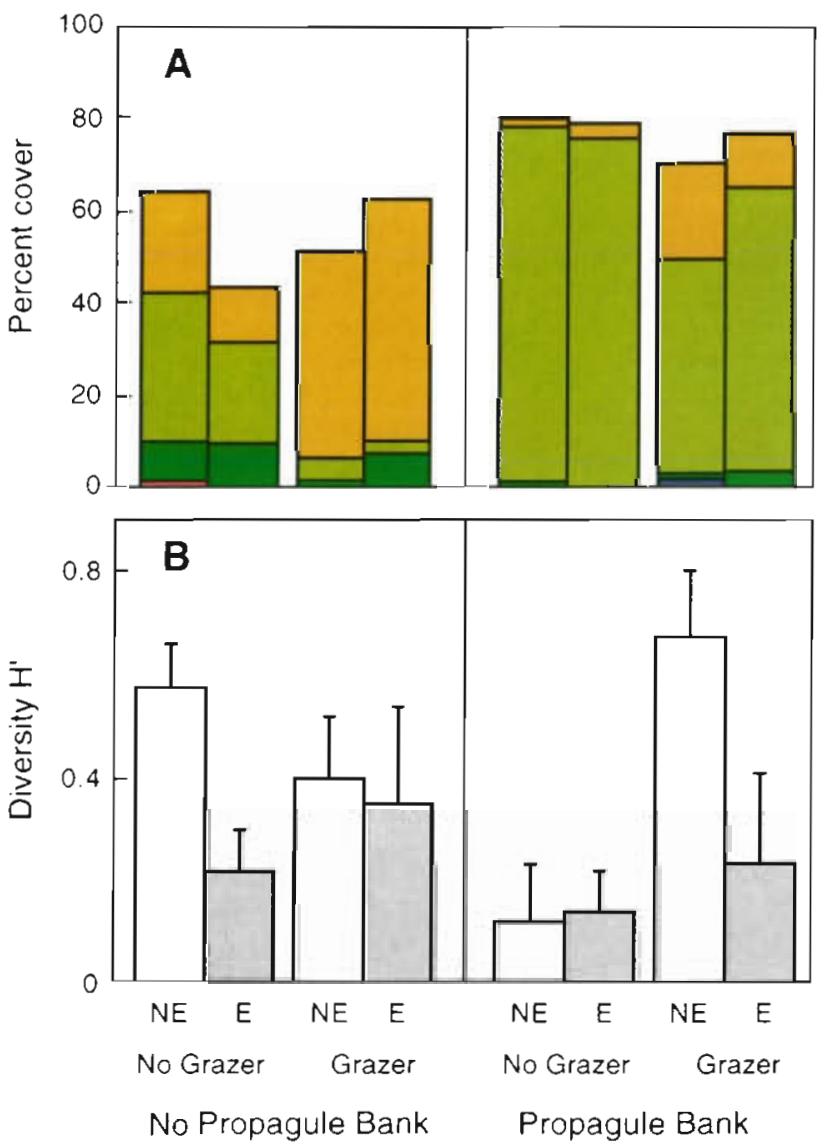
microrecruits (330 $\mathrm{cm}^{-2}$, Lotze et al. 1999). Their presence increases the dominance of this opportunistic annual. Grazers counteract this through selective consumption of Enteromorpha spp. germlings and adults (Lotze 1998). If only grazers are removed (propagule bank present), Enteromorpha spp. monopolizes space, a finding reported from other eutrophic environments (e.g. Lubchenco 1986). If only the propagule bank is removed (grazers present), a species mix can establish, which later becomes dominated by Fucus (Figs. 2A \& $3 \mathrm{~A}$ ). Nutrient enrichment shifts the community towards single species dominance when the 2 balancing factors

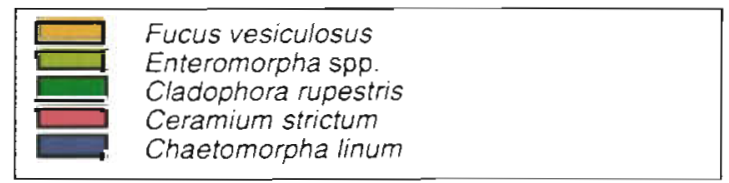

Fig. 3. Community response to nutrients (August, after 2 mo of enrichment). (A) Algal species composition and abundance and $(B)$ diversity ( $\pm 1 \mathrm{SE}$ ) are shown in relation to presence of grazers, algal propagule banks and low-level nutrient enrichment $(N E=$ no enrichment, $E=$ enriched). Significant interactions among the 3 experimental factors occurred (Table 1 ) 
(grazers and propagule banks) are both either absent or present. In the former (hypothetical) case, rapid nutrient-stimulated growth may partly compensate for delayed recruitment of annuals in the absence of the propagule bank. In the latter case (the natural situation), nutrients and early recruitment from propagule banks additively compensate grazing losses in Enteromorpha spp., which subsequently monopolizes space, blocking settlement and recruitment of fucoids and other algae (Hruby \& Norton 1979). Subsequent field experiments demonstrated a threshold level of $85 \%$ increase in the availability of DIN $\left(\mathrm{NH}_{4}{ }^{+}\right.$plus $\mathrm{NO}_{3}{ }^{-}$plus $\mathrm{NO}_{2}^{-}$), which completely overrides beneficial grazer effects on Fucus recruitment (B. Worm unpubl.).

Several positive feedbacks may accelerate this diversity shift. First, increasing abundance of annuals following nutrient enrichment could increase the abundance of stored propagules, which may enhance recruitment density of annual algae in the following year. Secondly, some grazer species require stands of perennial macrophytes as a habitat (Salemaa 1987) and decline when Fucus is lost, which will promote dominance of annual algae. Third, fucoid algae typically disperse propagules only within a few meters' radius (Chapman 1995), which limits their ability to re-invade lost habitat. Finally, once annuals become abundant they can form drifting mats that suffocate underlying organisms upon decomposition (Valiela et al. 1997). Commonly, such phenomena have been related solely to anthropogenic eutrophication which may simply favor species with high physiological capacities for nutrient uptake and growth. We propose a more complex scenario: subtle links between dormancy and dispersal strategies, consumer control and nutrient enrichment play an important role for the success of opportunistic annuals and may drive the largescale decline of perennial algae in the Baltic and possibly other systems where similar changes occur (Schramm \& Nienhuis 1996, Valiela et al. 1997). However, species-poor ecosystems like the Baltic are likely to be particularly vulnerable to such diversity shifts because of a lack of functionally equivalent species that may replace functionally important species such as Fucus upon their decline or extinction.

Acknowledgements. This study was supported by grants from the Deutsche Forschungs Gemeinschaft and the German Ministry of Education. We thank T. B. H. Reusch, A. R. O. Chapman, A. S. Chapman, R. T. Paine, J. L. Olsen, O. Rönnberg and $\mathrm{H}$. Hillebrand for comments on earlier drafts of this manuscript.

\section{LITERATURE CITED}

Carpenter SR, Caracao NF, Correll DL, Howarth RW, Sharpley AN, Smith VH (1998) Nonpoint pollution of surface waters with phosphorus and nitrogen. Ecol Appl 8:559-568
Chapman ARO (1995) Functional ecology of fucoid algae: twenty-three years of progress. Phycologia 34:1-32

Costanza R, d'Arge R, de Groot R, Farber S, Grasso M, Hannon B, Limburg K, Naeem S, O'Neill RV, Paruelo J, Raskin RG, Sutton P, van den Belt M (1997) The value of the world's ecosystem services and natural capital. Nature 387:253-260

Hruby T, Norton TA (1979) Algal colonization on rocky shores in the Firth of Clyde. J Ecol 67:65-77

Johnson CR, Field CA (1993) Using fixed-effects model multivariate analysis of variance in marine biology and ecology Oceanogr Mar Biol Annu Rev 31:177-221

Kautsky H, Kautsky L, Kautsky N, Kautsky U, Lindblad C (1992) Studies on the Fucus vesiculosus community in the Baltic Sea. Acta Phytogeogr Suec 787:33-48

Kautsky N, Kautsky H, Kautsky U, Waern M (1986) Decreased depth penetration of Fucus vesiculosus (L.) since the 1940 's indicates eutrophication of the Baltic Sea. Mar Ecol Prog Ser 28:1-8

Leibold MA, Wilbur HM (1992) Interactions between foodweb structure and nutrients on pond organisms. Nature 360:341-343

Lotze HK (1998) Population dynamics and species interactions in macroalgal blooms: abiotic versus biotic control at different life-cycle stages. Dissertation, Institut für Meereskunde, Kiel

Lotze HK, Schramm W, Schories D, Worm B (1999) Control of macroalgal blooms at early developmental stages: Pilayella littoralis versus Enteromorpha spp. Oecologia 119:46-54

Lubchenco J (1986) Relative importance of competition and predation: early colonization by seaweeds in New England. In: Diamond J, Case TJ (eds) Community ecology. Harper \& Row, New York, p 537-555

Nehring D (1987) Temporal variations of phosphate and inorganic nitrogen compounds in central Baltic deep waters. Limnol Oceanogr 32:494-499

Nehring D (1991) Recent nutrient trends in the western and central Baltic Sea. Acta Ichthyol Piscator 21(Suppl):153-162

Olenin S, Klovaite K (1998) Lithuanian marine and coastal biotopes. In: HELCOM red book on marine and coastal biotopes. HELCOM, Helsinki

Salemaa H (1987) Herbivory and microhabitat preferences of Idotea spp. (Isopoda) in the northern Baltic Sea. Ophelia $27: 1-16$

Santelices B, Hoffmann AJ, Aedo D, Bobadilla M, Otaíza R (1995) A bank of microscopic forms on disturbed boulders and stones in tide pools. Mar Ecol Prog Ser 129:215-228

Schramm W (1996) The Baltic Sea and its transition zones. In: Schramm $W$, Nienhuis PH (eds) Marine benthic vegetation-recent changes and the effects of eutrophication. Springer, Berlin, p 131-164

Schramm W, Nienhuis PH (eds) (1996) Marine benthic vegetation-recent changes and the effects of eutrophication. Springer, Berlin

Schulze D. Mooney HA (1993) Biodiversity and ecosystem function. Springer, Berlin

Sokal RS, Rohlf FJ (1995) Biometry. WH Freeman and Company, San Francisco

Valiela I, McClelland J, Hauxwell J, Behr PJ, Hersh D, Foreman K (1997) Macroalgal blooms in shallow estuaries: controls and ecophysiological and ecosystem consequences. Limnol Oceanogr 42:1105-1118

Vitousek PM, Mooney HA, Lubchenco J, Melillo JM (1997) Human domination of Earth's ecosystems. Science 277:494-499

Vogt H, Schramm W (1991) Conspicuous decline of Fucus in Kiel Bay (Western Baltic): what are the causes? Mar Ecol Prog Ser 69:189-194 
Worm B, Chapman ARO (1996) Interference competition among two intertidal seaweeds: Chondrus crispus strongly affects survival of Fucus evanescens recruits. Mar Ecol Prog Ser 145:297-301

Editorial responsibility: Otto Kinne (Editor),

Oldendorf/Luhe, Germany
Worm B, Chapman ARO (1998) Relative effects of elevated grazing pressure and competition by a red algal turf on two post-settlement stages of Fucus evanescens C. Ag. J Exp Mar Biol Ecol 220:247-268

Submitted: April 13, 1999; Accepted: July 16, 1999 Proofs received from author(s): August 9, 1999 